SCJR 13, no. 1 (2018): 1-2

\title{
Amy-Jill Levine and Marc Zvi Brettler, Eds. The Jewish Annotated New Testament, Second Edition
}

\author{
(Oxford and New York: Oxford University Press, 2017), \\ hardcover, $\mathbf{x x i x}+824$ pp.
}

MATTHEW THIESSEN

thiessem@mcmaster.ca

McMaster University, Hamilton, ON L8S 4L8, Canada

Since many of my students self-identify as Christians, one of my central goals in introductory courses to the New Testament has been to teach them the New Testament in a way that does not divorce it or its writers from the Judaism of the first century CE (or from the Greco-Roman world more broadly). While I have been able to exercise control over the content of my own lectures, I have rarely been satisfied with introductory textbooks, which often were understood to remove Jesus and the early Jesus movement from their Jewish milieu. Further, as someone who has been exposed to New Testament introductory courses in various roles (as a student, as a teaching assistant, and as a professor), I know how easy it is for students to read the textbook summary of a NT text instead of reading the actual text itself. Consequently, in 2011 I experimented with using the JANT as my primary textbook and found that it supported my pedagogical goals of (a) understanding the New Testament texts within their socio-historical context and (b) emphasizing student interaction with primary literature.

As happy as I have been with the first edition, the second edition is a substantial improvement and expansion. This expansion can be seen most clearly in the addition of 24 new topical essays to the original 30 . To give the reader a sense of the diversity of these essays, let me list a few of the topics covered: "Judaism and Jewishness," "Marriage and Divorce," "Pharisees," "Jewish Views of Gentiles," and "The New Testament and Jewish-Christian Relations." The 54 essays, taking up almost 200 pages, are succinct introductions to a vast array of topics that arise for readers of the New Testament. Supplementing these essays is a glossary of terms almost twenty pages in length.

More important to this reader, the second edition of JANT has also greatly supplemented the annotations that accompany the New Testament texts. What the JANT provides for all readers, Christian, Jewish, and other, is detailed evidence of 
the Jewish nature of the documents that now make up the New Testament. In contrast to most introductory textbooks, the JANT can function as a lifelong resource. Readers struggling with the meaning of this or that verse and how it might relate to Judaism can find a wealth of information in the annotations. In contrast to many other annotated or study Bibles, the JANT does not contain theological platitudes; rather, it presents illuminating references and comparisons to contemporaneous Jewish literature. It is, in other words, a treasure for people looking for a historically contextualized approach to reading the various documents that make up what we now call the New Testament in the milieu of early Judaism.

Briefly, let me note two lacunae in the volume. I do so not to quibble with the editors, who had to make difficult decisions about what to include. However, I want to suggest areas that they might address in any further editions and which would be of real value to Christian readers in particular. While both the introductory essay to the book of Revelation and the glossary briefly discuss apocalyptic literature, the genre of Jewish apocalypses (or apocalyptic thought more generally) merits its own essay. Christian readers would benefit from further information about such literature in order to counter the dominant discourse (in North America, at least) about the book of Revelation. Additionally, given both common misconceptions about ancient purity discourses and the fact that the Synoptic Gospel writers depict Jesus coming into contact with people who endure the three categories of ritual impurity (lepra [often erroneously translated as "leprosy"], genital discharges, and corpses), I was surprised to see no essay devoted to the concept of (ritual and moral) impurity in ancient Jewish thought.

In the preface to the first edition, Levine and Brettler articulate the hope that the JANT will help Jews and Christians better understand each other's common histories. This is both a noble and an ambitious goal. The JANT makes the New Testament accessible to Jewish readers while simultaneously making ancient Jewish texts accessible to Christian readers and providing them with a new lens through which to read their own scriptures. The popularity of the first edition and the publication of a second edition are a clear testament to the fact that readers have found their work an invaluable contribution to this laudable pursuit. We are indebted to Levine, Brettler, and their impressive collection of Jewish contributors for this wonderful resource. 